\title{
The participatory process for a regional spatial development concept in the UNESCO Biosphere Reserve Großes Walsertal
}

\section{Christine Klenovec}

Keywords: participation, acceptance, sustainable development, regional development concept

\section{Abstract}

Commissioned to work on a regional development concept for the UNESCO Biosphere Reserve Großes Walsertal (A), we needed to combine the overall concept for the biosphere reserve with the requirements of the spatial planning for the area. We adopted a participatory process to ensure high acceptance by the population. This article gives an overview of the process to create a regional development concept with plenty of participation.
Profile

Protected area

Biosphere Reserve

Großes Walsertal

Mountain range

\section{Starting point}

In 2018 the federal province of Vorarlberg commissioned the biosphere reserve (BR) region of Großes Walsertal to work out local spatial development plans (as an obligatory task) and a regional spatial development concept (as a desirable add-on). Such a regional spatial development concept is an enormous challenge in terms of regional cooperation far beyond the interests of individual municipalities. In the case of the BR Großes Walsertal, with six municipalities and a population of approximatly 3400 , this also means living up to its model role as UNESCO BR region.

In the same year, an opportunity arose to set up a REGIO management: the related agreed targets for 2020 included the statutory set-up of a REGIO office and the creation of a regional spatial development concept for the Großes Walsertal.

The Großes Walsertal became a UNESCO BR in the year 2000. The model role for the BR region was worked out in a participatory process following the UNESCO guidelines. It forms a binding development framework that is regularly evaluated and elaborated (Biosphärenparkleitbild 2019). The degree of participation is a kind of guarantee for a successful BR region. Preconditions for acceptance, identification and commitment from the population is a sufficient awareness of the value of goods to be protected, of livelihood basics and potentials, and handling it carefully (Aktuelle Projekte 2021). Therefore the only feasible way to create a regional spatial development concept was a participatory process.

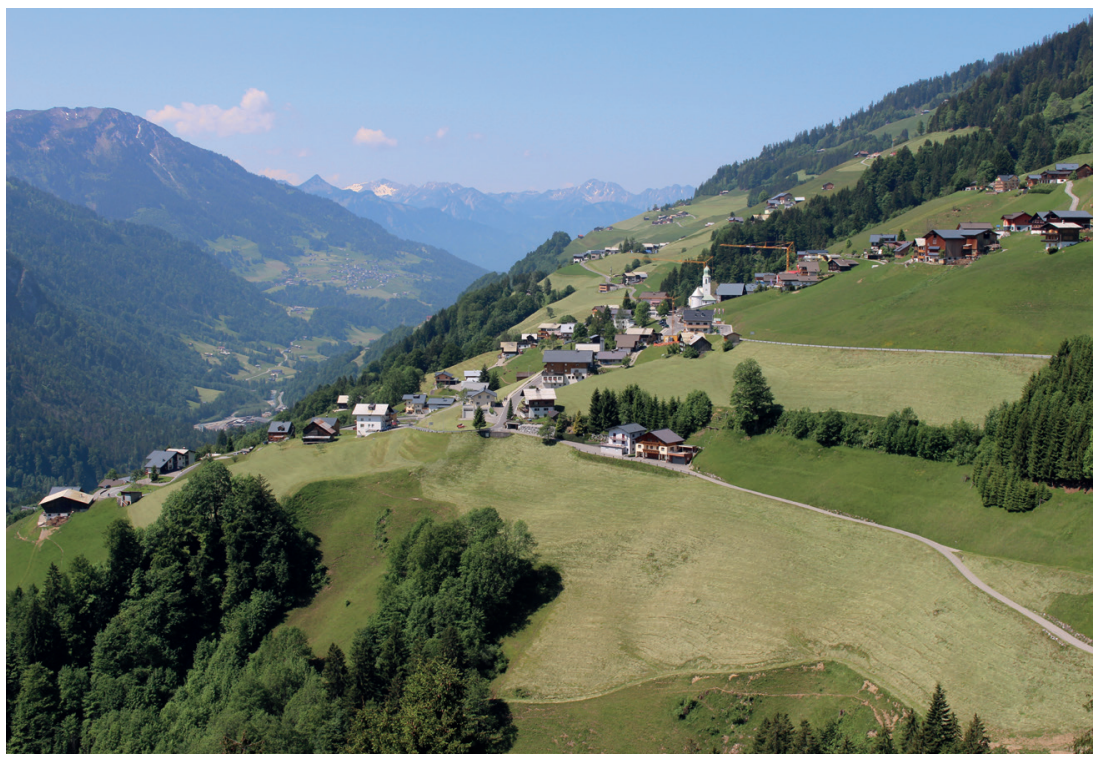

Figure 1 - BR Großes Walsertal, the village of Fontanella with a view into the valley with the typical shape of a scattered settlement. (C) C. Klenovec

\section{Concrete goal: a regional spatial develop- ment concept with a high degree of partici- pation}

Planner Markus Berchtold, who accompanied the process, sums up the goals of spatial development: "The goals defined in the regional spatial development concept (regREK) serve the six BR municipalities as a joint and coordinating guiding principle for their local spatial development plans. The spatial planning development efforts concentrate on the village centres and the existing hamlets and on the successful use of existing buildings and infrastructure. This requires the citizens to make continuous great private efforts to maintain the scattered settlement structure typical for the region. The concept adheres to the motto of the UNESCO BRs, Living and 
working in harmony with nature, and with the principles of the UNESCO BR model. The spatial planning strives to organize the BR region Großes Walsertal as a whole, with a view to benefiting the public. All affected interests are weighed up in such a way that they best serve the welfare of the whole valley. The planning spares private property as much as possible. The regREK does not describe a final state but the direction that development should take from today's perspective."

The aim was to provide an external expert to accompany the regional spatial development concept and to create it within a tight schedule. Those in charge were convinced that this would make it easier for all the people involved to stay with the project, even if their active period would be challenging. In fact, it became clear that the working group members involved were sometimes overwhelmed. So the quick creation of regional and local spatial development concepts was positive in leveraging synergies, but it was also a burden in that individual actors suffered multiple demands on their time.

It was necessary to harmonize issues with the federal province of Vorarlberg throughout and to design participation attractively. One challenge was creating sufficient opportunities for involvement at different levels to address and involve the population in a number of ways. This ranged from the general populace to representatives of the municipalities and political bodies to interest groups and individual actors. Different people wish to participate in different degrees, from just receiving information to interactive single information events to regular closer cooperation in working groups or conceptually in the process design.

\section{Participation in the process}

Creating a regional spatial development concept cannot primarily be defined as something the region wants, rather it is commissioned by the federal province of Vorarlberg. The result of this task, however, provides an additional valuable development framework for the region.

In spring 2018, a tender was called to find the desired external expert to accompany the project. It went to planners heimaten ${ }^{\circledR}$ - Innovation \& Identität im Raum. In summer 2018, a one-day meeting was held with the REGIO board, made up of the six mayors, the BR management and a few selected actors, to work out a process concept with a broad participation design.

The regional monthly magazine talschafft and the BR homepage reported regularly about individual steps as the project progressed and about options for participation. No targeted invitations were sent out for the themed working groups. Instead, in an effort to allow anyone interested to participate, several calls to participate were sent out, including one at a public kick-off event at Blons middle school, which included a talk and a discussion. The working groups started in autumn 2018, with expert support by the planners. At the same time, a steering group met regularly.
In an effort to give young people a voice, the BR management initiated a pupils project with the fourthyear classes of Blons middle school. It should find out how 14-year-olds, on the cusp of becoming adults, view spatial planning and to identify their needs. After all, they are the target group who will be in their midtwenties at the end of the regREK planning period in about ten years' time, directly facing spatial planning issues like housing design, job search, local provision or leisure design. The pupils approached the topic across subjects and presented it at the planning workshop with an added photo exhibition. Their presentation was taken up in the process. Even St. Gerold primary school picked up the topic of spatial planning for a small project.

The next, much valued, communication milestone for the population at large was the second planning workshop in spring 2019. The integration of new participation formats like a systemic spatial constellation was much appreciated. An additional event, a talk and debate with, among others, professor Martin Coy, representing a long-standing research cooperation between the University of Innsbruck and the BR region, brought in a view of spatial planning and sustainable development beyond the valley itself.

The very successful final milestone was a regional meeting of municipal representatives in autumn 2019 to jointly adopt the regional spatial development concept, which was passed by 61 of 62 councillors. A summary of the results was published in talschafft magazine and sent to every household. A more detailed version is available to anyone interested on the BR homepage (Regional Räumliches Entwicklungskonzept 2021).

Regina Rusch, who accompanied the process as REGIO manager until the end of 2020, sees a definite added value in the regional approach: "The spatial development process Großes Walsertal BR allowed regional actors to create a joint regional understanding of spatial development across municipal boundaries and to enhance cooperation between municipalities in the many conversations that took place. In the implementation of the planned measures we must now strive to underline the unique feature of our region as a model of sustainability and to continue on this trail-blazing path with courage."

\section{Limiting factors for participation}

Possible limiting factors for a high degree of active participation include a tight schedule, substantive requirements or a clear commission with a concrete result expected, limited individual resources of time with the actors, but also possible conflicts of interest. The external planner often had a mediating role, in this case sometimes not fulfilled with sufficient diplomacy, which led to some additional need for clarification between actors from the region and the federal province.

It is important to define, from the word go, clear rules of engagement and boundaries of what is feasible, so as to avoid unrealistic expectations by the 
people involved. If there are any conflicts of interest, the lowest common denomination needs to be found. In this process, examples would be debates about planned expansions of commercial areas near the core zone or the planned expansion of a skiing area. Here too, it is important to come together, to assess and balance interests and to uphold the region as a BR.

\section{Lessons learned}

Future similar projects would do well to strive for an even wider range of people involved (e.g. women, older people, etc.). To this end, other or additional formats may be needed, for instance, options for digital involvement, irrespective of defined periods of presence or population surveys.

The newer formats in particular, such as the planning workshop or the systemic spatial constellation, were very well received and taken up. They served to create deeper trust, provided options for ongoing adjustment outside the steering and working groups and also involved wider sections of the population. In sum, applying new participatory formats earns positive appreciation and responses.

The external experts neutralized debates in the working groups, which helped to constructively define the lowest common denominator in conflicts of interest, albeit with compromises for individual interests. The UNESCO criteria for living and working in harmony with nature are not always at the forefront for all actors, especially if individual interests exist. Here it is the task of the BR management to remind people, if needed, to raise awareness, to identify potential and defects, and to demand compliance with the BR criteria. Often such consensus-oriented conversations are enough to improve the outcome. On the issue of a possible expansion of the skiing area, for instance, it led to the feasibility study being enhanced to include stronger adherence to the BR model. In severe cases of conflicting interests, it will certainly need the support and clear requirements of the administration, because the BR management must never hamper but rather accompany a process.

A particularly successful aspect in the process was getting marginal groups involved, in this case the young people. Feedback confirmed that the young people themselves really enjoyed the participation, and in turn their presentation at the planning workshop was much appreciated.

The very tight schedule with clear goals set by the planner was both good and bad: It allowed working efficiently and in a targeted fashion, involving many people and serving a defined commision. However, such clear requirements possibly leave rather little room for open unprejudiced discussion.

\section{Conclusion - participation is always worth it}

In sum, we can call the participatory process an example of best practice. The population was offered many and varied options for participation and took them up.

Participation always means extra effort and resources, on the part of the people in charge as much as on the part of the population. The added value of a jointly carried decision-making process is worth it as it ensures high acceptance for the implementation to come. However, participation can never be more than an option that the population must take up of their own account. Those in charge and the management need to be skilled in strengthening the readiness of the population to remain involved in the longer term, to keep it alive and to offer suitable formats. Participation remains THE big challenge for BR regions; it takes passion and the will to learn and to reflect; but only with the necessary identification and active commitment will the development of the BR be carried by the population in decisions and implementation oriented on sustainable development.

In the words of Chair Josef Türtscher: "In adopting the regional spatial development concept Großes Walsertal, with all six municipalities, we have successfully put down a milestone for the future development of the region. This strategy paper is firmly based on the BR philosophy, which unites tradition, closeness to nature, a sense of the region, togetherness and openness to the wider world and to innovation."

\section{References}

Aktuelle Projekte 2021. Akzeptanz, Identifikation und Engagement. Available at: www.grosseswalsertal. at/Biosphaerenpark/Forschung/Aktuelle_Projekte/ AkIdEn (accessed 22/03/2021)

Biosphärenparkleitbild 2019. Leitbild. Available at: www.grosseswalsertal.at/Biosphaerenpark/Biosphaerenparkkonzept/Biosphaerenparkleitbild (accessed 22/03/2021)

Regional Räumliches Entwicklungskonzept 2021. Available at: www.grosseswalsertal.at/Regionales_Raeumliches_Entwicklungskonzept (accessed 22/03/2021)

\section{Author}

\section{Christine Klenovec}

studied ecology at the University of Vienna and completed the Masters Programme Management of Protected Areas at the University of Klagenfurt. Her profile includes further training in environmental education. Since 2006 she has worked in the management of protected areas, first as manager in Weißbach Nature Park (Salzburg); in 2014 she became manager of Großes Walsertal Biosphere Reserve. 